\title{
ANTIFERTILITY ACTIVITY OF DECASCHISTIA CROTONIFOLIA LEAF EXTRACT ON MALE RATS
}

\author{
AFSAR SHAIK ${ }^{1,2 *}$, PRASANNA RAJU YALAVARTHI ${ }^{3}$, CHANDRASEKHAR KOTHAPALLI BONNOTH ${ }^{4}$ \\ ${ }^{1}$ Faculty of Pharmaceutical Sciences, JNTUA, Ananthapuramu, Andhra Pradesh, India. ${ }^{2}$ Department of Pharmacology, Narayana \\ Pharmacy College, Nellore, Andhra Pradesh, India. ${ }^{3}$ Department of Pharmaceutics, Sri Padmavathi School of Pharmacy, Tirupati, \\ Andhra Pradesh, India. ${ }^{4}$ Department of Chemistry, Oil Technological and Pharmaceutical Research Institute, JNTUA, Ananthapuramu, \\ Andhra Pradesh, India. Email: afsarsk_14@yahoo.com
}

Received: 14 September 2018, Revised and Accepted: 10 December 2018

\section{ABSTRACT}

Objective: The objective was to investigate the male antifertility effect of Decaschistia crotonifolia leaf extract on male Wistar rats.

Methods: The animals were divided into three groups of five animals each. The first group (I) served as control and received normal saline, and remaining Groups II and III were treated with plant extract at a dose of 200 and $400 \mathrm{mg} / \mathrm{kg}$ p.o., respectively, for 21 days.

Results: Dose-dependent significant decrease in the weight of testes and epididymis was observed. Furthermore, a dose-related reduction in sperm count and motility was observed. A significant decrease in testosterone levels leading to infertility was also observed.

Conclusion: The $70 \%$ methanolic leaf extract of $D$. crotonifolia has produced dose-dependent antifertility effect on male rats.

Keywords: Male antifertility, Decaschistia crotonifolia leaf extract, Testosterone levels, Testes and epididymis.

(C) 2019 The Authors. Published by Innovare Academic Sciences Pvt Ltd. This is an open access article under the CC BY license (http://creativecommons. org/licenses/by/4. 0/) DOI: http://dx.doi.org/10.22159/ajpcr.2019.v12i3.29756

\section{INTRODUCTION}

Fertilization and control of overpopulation is a major quest in the modern era. Majority of people are facing problems such as infertility due to unremarkable reasons, and on the other hand, control of fertilization is also one of the targets of scientific community. Although a number of oral antifertility agents [1] are available in market, their usage is questionable due to their synthetic nature and a wide variety of side effects. Hence, a large number of population are migrating in a search for safe means of contraception. One of the most attracting and safest ways is using herbal medicine which is having a promising output with less or no side effects from the ancient times [2].

In the recent past, a majority of scientific and systemic investigations on herbal plants for their physicochemical and phytopharmacological properties including their antifertility activities are undertaken by researchers worldwide. As a part of contribution to the society, the present paper is focused on the research activity of Decaschistia crotonifolia for its antifertility activity.

D. crotonifolia is a widely grown plant in forests of Andhra Pradesh, Karnataka, Tamil Nadu, and Kerala. It belongs to the family Malvaceae, which is a shrub, growing at an height of $2 \mathrm{~m}$ [3]. A large source of wild plants possess a wide range of pharmacological uses, and hence, there is a need to explore uses of such plants to treat many diseases. An attempt was made to investigate antifertility potentials of $D$. crotonifolia as the investigations on this particular plant were very much limited.

\section{MATERIALS AND METHODS}

\section{Plant material}

D. crotonifolia leaves were collected from Talakona Forest, Tirupathi, and authenticated by botanist. The collected leaves were washed thoroughly in water and air-dried for 2 weeks at $35-40^{\circ} \mathrm{C}$. Extraction was carried out in $500 \mathrm{ml}$ of $70 \%$ methanol by soxhlation for $18 \mathrm{~h}$ using Soxhlet apparatus. The extract was concentrated under reduced pressure, dried, and stored in a desiccator.

\section{Animals used}

Healthy adult Wistar male rats (150-200 g) with proven fertility were marked and housed in polypropylene cages under a $12 \mathrm{~h}$ light and $12 \mathrm{~h}$ dark cycle. The experimental protocol was approved by the institutional animal ethical committee.

\section{Experimental design}

Animals were divided into three treatment groups containing five in each.

Group I - Animals in this group were treated as control and given distilled water alone for 3 weeks (21 days).

Group II - Animals in this group were treated as test I and given D. crotonifolia leaf extract at the dose of $200 \mathrm{mg} / \mathrm{kg}$ body weight p.o.

Group III - Animals in this group were treated as test II and given D. crotonifolia leaf extract at a dose of $400 \mathrm{mg} / \mathrm{kg}$ body weight p.o.

A suspension of extract was prepared in distilled water before administration. The required dose was administered orally with a syringe fitted with a feeding needle.

Sacrifice schedule

After their last dose at $21^{\text {st }}$ day, the rats were weighed and sacrificed under light ether anesthesia.

\section{Parameters monitored}

Body and organ weights

The animals were weighed before and after the treatment schedule to note the initial and final body weights. The testes and epididymides were dissected out, freed from tissues and blood, and weighed.

\section{Sperm count and motility}

About $100 \mathrm{mg}$ of each cauda epididymal tissue was minced in $1 \mathrm{ml}$ of physiological saline. For sperm motility, one drop of evenly mixed 
sample suspension was applied to a glass slide and provided with coverslip. The percentage of sperm motility was determined by counting both mobile and immobile spermatozoa per unit area.

\section{Radioimmunoassay of testosterone hormone}

Blood samples were collected to estimate the levels of serum testosterone by radioimmunoassay (RIA) method.

\section{Statistical analysis}

All the data were expressed as mean \pm SEM. Statistical significance between two and above groups was tested using one-way ANOVA method followed by Tukey test using Prism GraphPad.

\section{RESULTS}

\section{Body and organ weights}

All the animals in three groups had shown a marked increase in their body weights with respect to their initial weights. The final body weights of both Group II (200 mg/kg) and Group III ( $400 \mathrm{mg} / \mathrm{kg}$ ) have significantly increased when compared to the final weight of Group I (control group) animals. On the other hand, a great decrease in the weights of testes and epididymides was observed in all treatment groups (Groups II and III) when compared to Group I animals (Table 1).

\section{Sperm motility and count}

In Groups II and III, a significant decrease in percentage epididymal sperm motility was observed when compared with Group I animals. After 21 days of treatment, only $36.4 \pm 8.3 \%$ and $31.5 \pm 5.8 \%$, respectively, of spermatozoa versus $59.2 \pm 3.2 \%$ of spermatozoa in Group I were found to be motile. The sperm count was also decreased significantly in all treatment groups (Table 2).

\section{Hormone profile (testosterone)}

The mean serum testosterone levels in Groups II and III tended to lower than that of Group I, namely $8.42 \pm 0.004,1.82 \pm 0.01$, and $11.63 \pm 0.04 \mathrm{ng} / \mathrm{ml}$ for II, III, and I, respectively (Table 3 )

\section{DISCUSSION}

In the present study, findings showed that the methanolic leaf extract of D. crotonifolia could significantly alter the male fertility potentials. The data observed and obtained from the present have shown that the 70\% methanolic extract of $D$. crotonifolia leaf extract suppresses epididymal and testicular sperm count [4]. The significant increase in body weights on treated animals indicates that the extract may have a toxic effect on the rats. The significance in the absolute weight of testes and epididymis could be, therefore, due to an increased androgen synthesis as evidence serum testosterone level [5]. The extract also further reduced serum testosterone levels after 21 days of treatment and it may be related to a well-known concept that luteinizing hormone (LH) is basically responsible for testosterone production [6]. Yet another possibility of lower sperm concentration by the extract may be due to oxidative stress [7]. However, it is also observed that the serum testosterone level correlates with sperm count and motility [8].

In fact the motility and fertility ability are markers of a healthy sperm, any sort of negative impact on motility can lead to serious effect on fertility ability [9]. The remarkable decrease in motility and sperm count strongly points out to a spermicidal activity of $D$. crotonifolia, and the extract may lead to androgen depletion at the target maturation of the sperm [10]. All the above findings strongly potentiate the medicinal properties of traditional plants as herbal medicines have played an important role in the foundation of current pharmacopeia [11]. Today, most useful drugs can be synthesized by natural products [12].

\section{CONCLUSION}

The $70 \%$ methanolic extract of D. crotonifolia leaf has produced dosedependent effect on male fertility and reproduction. The effect may have
Table 1: Body and organ weights after 21 days of treatment with $70 \%$ methanolic extract of $D$. crotonifolia leaf on male rats

\begin{tabular}{llllll}
\hline S. No & Treatment & \multicolumn{2}{l}{ Body weights (g) } & Testes & Epididymis \\
\cline { 3 - 4 } & groups & Initial & Final & & \\
\hline 1 & Group I & $198 \pm 9.5$ & $235 \pm 14.0$ & $109.3 \pm 0.65$ & $56.2 \pm 1.23$ \\
2 & Group II & $197 \pm 12.3$ & $256 \pm 12.3$ & $82.6 \pm 0.92$ & $39.3 \pm 1.45$ \\
3 & Group III & $200 \pm 10.5$ & $298 \pm 21.6$ & $62.3 \pm 0.75$ & $24.6 \pm 0.84$ \\
\hline
\end{tabular}

Data are expressed as mean \pm SD, $\mathrm{mg} / 100 \mathrm{~g}$ of body weight, $\mathrm{p}<0.01$ compared with corresponding initial body weight. SD: Standard deviation

Table 2: Sperm morphology after 21 days of treatment with $\mathbf{7 0} \%$ methanolic extract of Decaschistia crotonifolia leaf on male rats

\begin{tabular}{lllll}
\hline S. No & $\begin{array}{l}\text { Treatment } \\
\text { groups }\end{array}$ & $\begin{array}{l}\text { Sperm motility } \\
\text { count }(\%) \text { Cauda } \\
\text { epididymis }\end{array}$ & $\begin{array}{l}\text { Sperm count } \\
\text { (million } / \mathbf{m m}^{3} \text { ) }\end{array}$ \\
\cline { 4 - 5 } & & Testes & $\begin{array}{l}\text { Cauda } \\
\text { epididymis }\end{array}$ \\
\hline 1 & Group I & $59.2 \pm 3.2$ & $4.6 \pm 0.2$ & $48.0 \pm 3.3$ \\
2 & Group II & $36.4 \pm 8.3$ & $2.5 \pm 0.7$ & $25.6 \pm 6.6$ \\
3 & Group III & $31.5 \pm 5.8$ & $1.8 \pm 0.5$ & $16.0 \pm 1.6$ \\
\hline
\end{tabular}

Data are expressed as mean \pm S.D., $n=5, p<0.01$ Compared with group I .SD: Standard deviation

Table 3: Effect of the methanolic extract of Decaschistia crotonifolia leaf on hormone profile of male Wistar rats

\begin{tabular}{lll}
\hline S. No & Treatment groups & Testosterone \\
\hline 1 & Group I & $11.63 \pm 0.04$ \\
2 & Group II & $8.42 \pm 0.004$ \\
3 & Group III & $1.82 \pm 0.01$ \\
\hline
\end{tabular}

Data are expressed as mean \pm S.D., $n=5, p<0.01$ Compared with group I.SD: Standard deviation

a decreased influence on LH release which may be responsible to incline testosterone release. Further, an extensive evaluation of complete reversible fertility should be done on this particular important plant.

\section{AUTHORS' CONTRIBUTIONS}

All the three authors have equally contributed for the final shape of the manuscript. Precisely, authors Dr. Prasanna Raju Yalavarthi and Dr. Chandrasekhar Kothapalli Bonnoth have designed the experimental study, Mr. Shaik Afsar has prepared the manuscript, and all the three authors have finalized the final output of manuscript.

\section{CONFLICTS OF INTEREST STATEMENT}

We declare no conflicts of interest.

\section{REFERENCES}

1. Benzophenous A. Napthophenones and related compounds as spermicidal agents. Indian J Pharm Sci 1994;56:105-8.

2. Satyaraj K, Sivaraj A, Kumari PV, Devi K, Kumar BS. Spermicidal activity of Azardicta indica (Neem) aqueous leaf extract on male albino rats. Int J Pharm Tech Res 2010;2:588-91.

3. Shaik A, Yalavarthi PR, Banoth CS. Review on Dechachistia crotonifolia wight and Arn. J Compr Pharm 2016;3:89-90.

4. Malli PC, Ansari AS, Chaturvedi M. Antifertility effect of chronically administered Martynia annua root extract on male rats. J Ethnopharmacol 2002;82:61-7.

5. Morakinyo AO, Adeniyi OS, Arikawe AP. Effect of Zingiber officinale on reproductive functions in the male rat. Ajri J Bio Met 2008;11:329-34.

6. Ewing LL, Davis JC, Zirkin BR. Regulating testicular function: A special and temporal view. Int Rev Physiol 1980;22:41-5.

7. Ghosh D, Das UB, Ghosh S, Mallick M, Debnath J. Testicular gametogenic 
and steroidogenic activities in cyclophasphamide treated rats: A correlative study with testicular oxidative stress. Drug Chem Tox 2002;25:281-91.

8. Carropo E. Niederberger C, Lacovazzi PA, Palaguano AD, Amato G Humn chrorionic gonadotrophin. Free Sub unit in the humn seminal plasma. A new marker for spermatogenesis. Eur J Obster Gynecol 2003;106:165-9.

9. Akbarsha MA, Murugaian P. Antifertility of the male reproductive toxicity/male antifertility property of andrographolide in albino rats: Effect on the testes cauda epididymal spermatozoa. Phytother Res
2000;14:432-5.

10. Chinoy NJ, Dsouza TM, Padman P. Contraceptive efficacy of Carca papaya seed extract in male mice. Phytoptherapy 1995;9:30-6.

11. Baskar V, Meeran IS, Subramani A, Jawahar AS, Shabeer TK. Historic review on modern herbal nanogel formulation and delivery methods. Int J Pharm Pharm Sci 2018;10:1-10.

12. Kumar PP, Kumar MS, Kamal S, Nishi S. Anticancer and antimicrobial potential of Barleria prionitis leaves ethanol extract. Int J Pharm Pharm Sci 2018;10:100-3. 